\title{
Medisinsk termografi - alternativ diagnostikk?
}

\author{
Kroppens varmeproduksjon har gjennom alle tider hatt betydning for medisinsk diagnostikk og behandling. \\ Moderne infrarøde varmekameraer har høy temperatursensitivitet og lager «varmebilder» med svært stor \\ oppløselighet.
}

Alle objekter som er varmere enn det absolutte nullpunkt $\left(-273,15^{\circ} \mathrm{C}\right)$ vil i større eller mindre grad avgi infrarød stråling. Infrarød stråling ligger mellom synlig lys og mikrobølger og har forskjellig intensitet etter temperaturen i overflaten. Et infrarødt kamera får frem bilder av et objekts varmestråling. Et slikt bilde kalles et termogram.

Termografi har allerede vært i bruk i mange år der det er hensiktsmessig å oppdage og dokumentere små varmeforskjeller. I bygningsindustrien kan man ved hjelp av termografi for eksempel påvise trekk, fukt og dårlig isolasjon i hus samt varmgang og overbelastninger i elektriske anlegg. Et annet eksempel er redningstjenesten, der varmesøkende kameraer benyttes for å finne overlevende, både på havet, i snøen og på fjellet. Forskning og teknologiutvikling innen militære bruksområder har de siste tiår bidratt vesentlig til dagens moderne termografi.

\section{Opptak av termogrammer}

Bruk av termografiske kameraer krever et minimum av kunnskap om grunnleggende termofysikk. Den infrarøde varmestrålingen

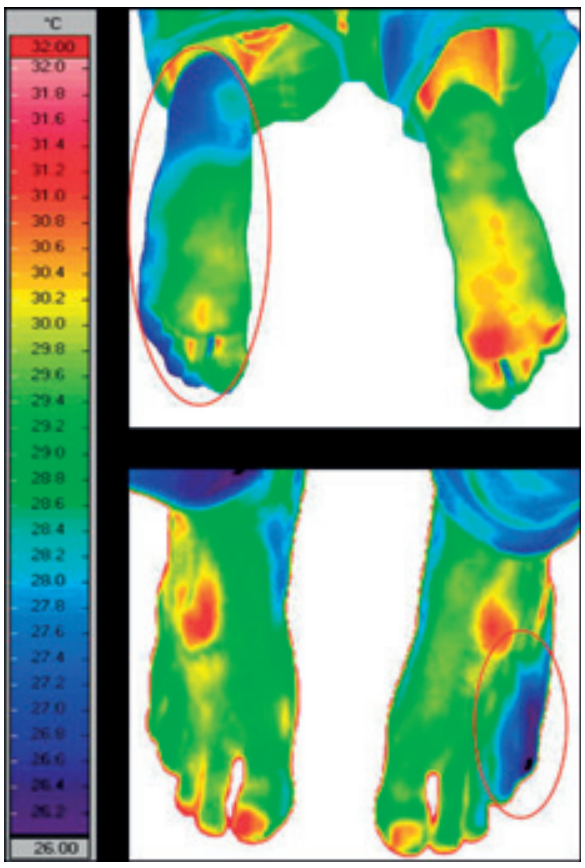

Figur 1 Infrarødt termogram fra en pasient der det var klinisk mistanke om kuldeskade (non-freezing cold injury, NFCl) etter en militærøvelse. Pasientens smerte $i$ venstre fot var i samme område som det ble påvist redusert temperatur (markert med oval sirkel) har bølgelengder på mellom $700 \mathrm{~nm}$ og $1 \mathrm{~mm}$, og strålingen påvirkes av kvaliteter ved strålelegemet, av opptaksmiljøet og det infrarøde kameraet.

Objekters evne til varmestråling er avhengig av temperaturen og evnen til å avgi varme. Ut fra termofysikkens lover kan energien uttrykkes i matematiske størrelser. Varmestrålingen kan oppfanges i detektorsystemer i infrarøde kameraer, konverteres til elektriske signaler og avtegnes i termografiske bilder.

Det siste tiåret har multielementdetektorsystemer (focal plane array) og høyere oppløselighet gjort at stadig mindre temperaturforskjeller kan avtegnes. Sanntidsskanning (real-time scanning) og avansert bildebehandling gjør at den infrarøde strålingen i løpet av sekunder ses på en dataskjerm. Termogrammet kan deretter bearbeides og lagres.

\section{Infrarød stråling hos mennesket} Menneskekroppens varmestråling ligger nær opp til den man finner hos et ideelt «svart legeme» (emissivitet $=0,98)$. Kroppens infrarøde stråling er imidlertid lett å tildekke, og kroppsbehåring, hudens attributter og selvsagt alt av klær og annen bekledning påvirker varmestrålingen i varierende grad. En naken person i rom-

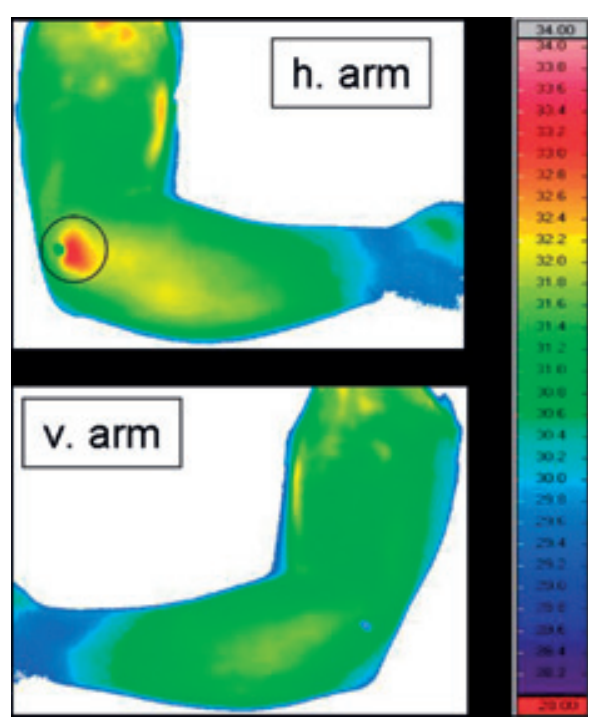

Figur 2 Infrarødt termogram hos en pasient der det var klinisk mistanke om lateral epikondylitt i høyre albue. Pasienten hadde maksimal palpasjonsømhet i samme område som det ble påvist økt temperatur (markert med sirkel) temperatur $\left(20^{\circ} \mathrm{C}\right)$ avgir om lag $60 \%$ av kroppsvarmen via stråling.

Medisinsk termografi er basert på måling av hudens overflatetemperatur. Denne temperaturen er avhengig av blodsirkulasjon i de ytterste millimeter av huden, en blodstrøm underlagt komplisert regulering via nervesystemet og lokale faktorer. Man kan således ikke «se» indre organer ved hjelp av termografi, men patologiske prosesser som for eksempel svulster, inflammasjoner og vevsskade i underliggende strukturer kan gi vaskulære responser som kan avtegne ulike varmemønstre ved infrarød fotografering (fig 1, fig 2) (1).

\section{Medisinsk termografi}

Første gang av termografi ble brukt medisinsk var i 1957, da det ble avdekket at hudtemperaturen over en overfladisk kreftsvulst var høyere enn temperaturen i omliggende normalt vev (2). Selv om metoden aldri har fått fotfeste innen den etablerte kunnskapsbaserte medisin, pågår det mye forskning for å kartlegge bruken.

Ved noen undersøkelser er det nødvendig å kjøle ned hudtemperaturen for deretter å ta bilder kontinuerlig i en oppvarmingsfase. Nedkjølingen kan foregå ved hjelp av kaldt vann eller en vifte. En slik undersøkelsesteknikk blir kalt dynamisk infrarød termografi (DIRT). Denne teknikken kan man for eksempel bruke ved Raynauds fenomen, der oppvarming av en avkjølt hånd vil ta lang tid, med et karakterisk mønster som er veldig ulikt det man ser hos friske mennesker (3).

Det er også andre områder innen medisinen der termografi kan gi diagnostisk informasjon - revmatologi, dermatologi, ortopedi og vaskulære funksjonsforstyrrelser er noen eksempler $(4,5)$. Også ved brannskader (6), frostskader (7) og kreftsykdom (8) er resultatene interessante. Innen kirurgien, særlig gjelder dette transplantasjonskirurgi og plastikkirurgi, er termografi allerede i klinisk bruk (9-11).

\section{Termografi i USA}

I 1982 ble termografi anerkjent av det statlige Food and Drug Administration (FDA) som adjuvant kartlegging av brystkreft. Ukritisk bruk av metoden med til dels dårlig utstyr, samt lav validitet og reliabilitet ved tolking av termografiske bilder, førte etter en initial optimisme i løpet av få år til kollaps i bruken av termografi. Samtidig viste forskning fra flere land svakheter 
med metoden, særlig gjaldt det sensitivitet og spesifisitet innen kreftdiagnostikken $(12,13)$.

Det siste tiåret har mulighetene innen medisinsk termografi bedret seg betraktelig. Omfattende forskning har bidratt til økende oppmerksomhet omkring bruk av denne teknologien innen både human- og veterinærmedisinen $(14,15)$. Teknologiske fremskritt har ført til mer eksakt diagnostikk, og det har vært en utvikling mot valide og reliable kriterier for tolking av medisinske termogrammer $(1,16)$. Industrien har sett potensialet i dette, og det har utviklet seg markedsmessige konkurranseforhold der gevinsten for pasienten kanskje kan være usikker?

\section{Norsk termografi}

Ved Universitetet i Tromsø og Universitetssykehuset Nord Norge har forskning på termografi fått et akademisk fotfeste med to nylig avlagte doktoravhandlinger på feltet $(17,18)$. Kardiovaskulær forskningsgruppe har generert internasjonal interesse gjennom et Internett-basert senter for termografi (19). Arbeidet ledes av professor James Mercer, som også er leder for European Association of Thermology (20).

Den kliniske bruken av termografi i Norge er imidlertid fortsatt sparsom. Med nye høyteknologiske termografiske kameraer og flere nye forskningsprosjekter vil interessen kunne øke. Fortsatt er det behov for mer omforent vitenskapelig dokumentasjon, og det tar trolig enda noe tid i norske fagmiljøer å vinne erfaring med pålitelig tolking av termografiske bilder.

Når man i dag skal ta stilling til bruk av termografi, er det imidlertid viktig å være klar over at fagområdet er i rask utvikling kunnskap fra et par tiår tilbake er utdatert. Mens termografi tidligere var sett på som alternativ diagnostikk, kan metoden nå være på vei inn i etablert medisinsk praksis $(1,21-23)$.

\section{Arne Johan Norheim}

arne.johan.norheim@hlkbb.no

Nasjonalt forskningssenter innen komplementær og alternativ medisin

\section{James Mercer}

Kardiovaskulær forskningsgruppe

Det helsefaglige fakultet

Universitetet i Troms

Arne Johan Norheim (f. 1961) er spesialist i allmennmedisin ved Vitalisklinikken i Harstad. Han har en doktorgrad innen akupunktur og arbeider som seniorforsker ved Nasjonalt forskningssenter innen komplementær og alternativ medisin (NAFKAM), Universitetet i Troms $\varnothing$. For tiden arbeider han med kartlegging av effekten av akupunkturbehandling ved hjelp av termografi.

Ingen oppgitte interessekonflikter.

James Mercer (f. 1949) er professor ved kardiovaskulær forskningsgruppe ved det helsevitenskapelige fakultet, Universitetet i Troms $\varnothing$, og leder av the European Association of Thermology. Ingen oppgitte interessekonflikter.

\section{Litteratur}

1. Bronzino JD. Advances in medical imaging. The biomedical engineering handbook. Medical devices and systems. 3. utg. Kap 19. New York: CRC press, 2006: 1-14.

2. Lawson RN. Thermography; a new tool in the investigation of breast lesions. Can Serv Med 1957; 8: 517-24.

3. Pors-Nielsen S, Mercer JB. Dynamic thermography in vascular finger disease - a methodological study of arteriovenous anastomoses. Thermology International 2010; 20: 93-9.

4. Jiang LJ, Ng EY, Yeo AC et al. A perspective on medical infrared imaging. J Med Eng Technol 2005; 29: 257-67

5. Diakides NA, Bronzino JD. Thermal imaging in diseases of the skeletal and neuromuscular systems. Medical infrared imaging. Ka. 17. New York: CRC Press, 2007, 1-15.

6. Kaiser M, Yafi A, Cinat $M$ et al. Noninvasive assessment of burn wound severity using optical technoogy: a review of current and future modalities. Burns 2011; 37: 377-86

7. Imray C, Grieve A, Dhillon S et al. Cold damage to the extremities: frostbite and non-freezing cold injuries. Postgrad Med J 2009; 85: 481-8.
8. Kennedy DA, Lee T, Seely D. A comparative review of thermography as a breast cancer screening technique. Integr Cancer Ther 2009: 8: 9-16.

9. De Weerd L, Weum S, Mercer JB. The value of dynamic infrared thermography (DIRT) in perforator selection and planning of free DIEP flaps. Ann Plast Surg 2009: 63: 274-9.

10. De Weerd L, Mercer JB, Weum S. Dynamic infrared thermography. Clin Plast Surg 2011; 38: 277-92.

11. Okada Y, Kawamata T, Kawashima A et al. Intraoperative application of thermography in extracranial-intracranial bypass surgery. Neurosurgery 2007; 60 (4 Suppl 2): 362-5.

12. Feig SA, Shaber GS, Schwartz GF et al. Thermography, mammography, and clinical examination in breast cancer screening. Review of 16,000 studies. Radiology 1977; 122: 123-7.

13. Moskowitz M, Milbrath J, Gartside P et al. Lack of efficacy of thermography as a screening tool for minimal and stage I breast cancer. N Engl J Med 1976: 295: 249-52.

14. Merla A, Romani GL. Functional infrared imaging in medicine: a quantitative diagnostic approach. Conf Proc IEEE Eng Med Biol Soc 2006; 1: $224-7$.

15. Diakides NA, Bronzino JD. Use of infrared imaging in veterinary medicine. Medical infrared imaging. Kap 21. New York: CRC Press, 2008: 1-21.

16. Diakides NA, Bronzino JD. Physiology of thermal signals. Medical infrared imaging. Kap. 20. New York: CRC Press, 2008: 1-20.

17. Miland $\AA 0$. Dynamic infrared thermography in the assessment of skin perfusion - a clinical and experimental study. Doktoravhandling. Troms $\varnothing$ : Universitetet i Tromsø, 2008

18. De Weerd L. Free perforator flap surgery and dynamic infrared thermography - a clinical and experimental study. Doktoravhandling. Troms $\varnothing$ : Universitetet i Tromsø, 2010

19. The Northern Norwegian Centre for Medical Thermography. www.medical-thermography.com (18.8.2011)

20. The European Association of Thermology. http:// europeanthermology.com/cms32/index.php (18.8.2011).

21. Ring EF, Ammer K. The technique of infrared imaging in medicine. Thermology International 2000; 10: 7-14

22. Plassmann P, Ring EF, Jones CD. Quality assurance of thermal imaging systems in medicine. Thermology International 2006; 16: 10-5.

23. Diakides NA, Bronzino JD. Advances in medical infrared imaging. Medical infrared imaging. Kap. 1 New York: CRC Press, 2008, 1-13.

Mottatt 23.5. 2011, første revisjon innsendt 17.7. 2011, godkjent 18.8. 2011. Medisinsk redaktør Anne Kveim Lie.

\title{
Turnussaken
}

\author{
Ole Brumms filosofi kan komme til nytte i debatten om turnustjenesten
}

De siste to årene har turnussaken vært diskutert i Legeforeningens fora, og temaet trekning eller søknadsbasert ordning har vært et av hovedspørsmålene $(1,2)$. Etter lang tids debatt ser det ikke ut som om man har kommet noe nærmere hvordan dette skal løses i praksis.

Kan vi igjen nytte oss av Ole Brumms filosofi: Ja takk, begge deler? Man kan søke sentralt om å få være med på trekningen. Da kan man sile ut alle dem som ikke trenger turnus - og deretter trekke blant dem som skal ha turnus, slik vi har gjort til i dag. Dermed er begge hovedønsker ivaretatt: Vi får en ordning som greit lar seg administrere og legefordelingen kan sikres som i dag.

\section{Per Kr. Skorpen}

perkrskorpen@gmail.com

Nordlandssykehuset Vesterålen
Per Kristian Skorpen (f. 1953) er spesialist $\mathrm{i}$ indremedisin og overlege ved Medisinsk avdeling, Nordlandssykehuset Vesterålen. Ingen oppgitte interessekonflikter.

Litteratur

1. Janbu T. Turnustjeneste. Tidsskr Nor Legeforen 2010; 130: 1855

2. Braaten KE. Ny søknadsbasert turnustjeneste. www.legeforeningen.no/id/168534.0 (30.3.2011) 